\title{
Evaluation of the Polyphenolic, Nutritive and Biological Activities of the Acetone, Methanol and Water Extracts of Amaranthus asper
}

\author{
Jimoh F.O. ${ }^{1}$, Adedapo A. A. ${ }^{2}$, Aliero A.A. ${ }^{1}$, Koduru S. ${ }^{1}$ and Afolayan A. J. ${ }^{*}, 1$ \\ ${ }^{1}$ Department of Botany, University of Fort Hare, Alice 5700, South Africa \\ ${ }^{2}$ Department of Veterinary Physiology, Biochemistry and Pharmacology, University of Ibadan, Nigeria
}

\begin{abstract}
The nutritional, phytochemical, antioxidant and antibacterial activities of the acetone, methanol and water extracts of the leaves of Amaranthus asper were investigated using standard analytical methods in order to assess the numerous potential of the plant leaves. The proximate analysis showed that the leaves of this plant contained moisture, ash, crude protein, crude lipid, crude fibre, energy and carbohydrate. Elemental analysis in $\mathrm{mg} / 100 \mathrm{~g}$ (DW) indicated that the leaves contained sodium (0.0373), potassium (2.872), calcium (2.504), Magnesium (0.569), Iron (419), Zinc (26), phosphorus (0.177), Copper (18), Manganese (91), and Nitrogen (1.78). The chemical composition in $\mathrm{mg} / 100 \mathrm{~g}$ (DW) for alkaloid, saponins, and phytate were $0.3,7.0$ and 9.25 respectively. Comparing the nutrient and chemical constituents with recommended dietary allowance (RDA) values, the results reveal that the leaves contain an appreciable amount of nutrients, minerals, and phytochemicals and low levels of toxicants. At 1mg/ml, the acetone extract caused 98.2\% ABTS radical scavenging inhibition while the methanol, water and BHT caused inhibition at 95.4, 97.1 and 99.3\% respectively. The result for DPPH scavenging activity was close to that of ABTS. The plant was also rich in the different polyphenols analyzed in this study. The ferrous reducing antioxidant power (FRAP) values for acetone extract (1084.9) is much higher than that of methanol (143.5), water (42.4), BHT (63.5), and catechin (972.02) but lower than those of ascorbic acid (1632.1) and quercetin (3107.3). The methanol extract has antibacterial activity against all the Gram-positive organisms used in this study. This study has to some extent validated the need for the use of the leaves of Amaranthus asper for nutritional and medicinal purposes.
\end{abstract}

Keywords: Antibacterial properties, antioxidant activities, polyphenolics, Amaranthus asper, nutritional value.

\section{INTRODUCTION}

Most developing countries depend on starch-based foods as the main staple food for the supply of both energy and protein. This accounts in part for protein deficiency which prevails among the populace as recognized by Food and Agricultural Organization [1, 2]. In Nigeria, as in most other tropical countries of Africa where the daily diet is dominated by starchy staple foods, vegetables are the cheapest and most readily available sources of important proteins, vitamins, minerals and essential amino acid [2]. Many of the local vegetable materials are under-exploited because of inadequate scientific knowledge of their nutritional potentials. Many workers [3-7] have reported the compositional evaluation and functional properties of various types of edible wild plants in use in the developing countries. Though several works reporting compositional evaluation and functional properties of various types of edible wild plants in use in the developing countries abound in literature, much still need to be done.

Amaranthus asper L, popularly called "Amaranth or pigweed", is an annual herbaceous plant of 1- 6 feet high. It belongs to the family Amaranthaceae. Other synonyms for this plant are A. hybridus and A. albus. The leaves are alternate petioled, $3-6$ inches long, dull green, and rough,

*Address correspondence to this author at the Department of Botany, University of Fort Hare, Alice 5700, South Africa; Tel: +27406022323; Fax: +27866282295; E-mail: aafolayan@ufh.ac.za hairy, ovate or rhombic with wavy margins. The flowers are small, with greenish or red terminal panicles. Taproot is long, fleshy red or pink. The seeds are small and lenticellular in shape; with each seed averaging $1-1.5 \mathrm{~mm}$ in diameter and 1000 seeds weighing $0.6-1.2 \mathrm{~g}$. It is rather a common species in waste places, cultivated fields and barnyards [2]. In Nigeria, A. hybridus leaves combined with condiments are used to prepare soup [8]. In Congo, their leaves are eaten as spinach or green vegetables [9]. These leaves boiled and mixed with a groundnut sauce are eaten as salad in Mozambique and in West Africa [10,11]. A. hybridus has been shown to contain large amount of squalene, a compound that has both health and industrial benefits [1214]. Despite the use of this plant for such purposes, there is little information on the nutritional and chemical composition of A. asper leaves.

One noticed with dismay the fact that few vegetables species were consumed in South Africa by the general populace. Although 32 plants were documented as wild vegetables species utilized in Transkei, Eastern Cape Province (about 120 kilometers from Alice), their nutritional qualities were not reported. The interview conducted during the course of our research in Alice and its surrounding villages indicated that many of these species, though known, are considered as weeds and were not eaten by the people. This is in spite of the fact that these vegetables grow spontaneously and in abundance around the rural homesteads. Reports of studies carried out on wild vegetables in different parts of the world as already indicated show that many wild 
vegetables had higher protein, mineral and vitamin contents than the cultivated vegetables like spinach and cabbage. The consumption of vegetables has also been linked to reduction in the incidence of oxidative-stress related diseases such as cancer, diabetes, [15-17] and neurodegenerative diseases, including Parkinson's and Alzheimer's diseases [18] as well as inflammation and problems caused by cell and cutaneous aging $[19,20]$. This is due to beneficial health functionality of phenolic antioxidants present in them.

Also, natural products from microorganisms have been the primary source of antibiotics, but with the increasing acceptance of herbal medicine as an alternative form of health care, the screening of medicinal plants for active compounds has become very important because these may serve as promising sources of novel antibiotic prototypes [21-23]. It has been shown that in vitro screening methods could provide the needed preliminary observations necessary to select crude plant extracts with potentially useful properties for further chemical and pharmacological investigations [24].

Amaranthus asper was one of the wild vegetables identified and the study was therefore aimed at assessing its nutritional quality and possible biological activities.

\section{MATERIALS AND METHODS}

\section{Plant Collection and Extract Preparation}

Fresh plant material of Amaranthus asper was collected in November 2006 from the wild around the University of Fort Hare campus (Alice, South Africa). The area falls within the latitudes $30^{\circ} 00-34^{\circ} 15^{\prime} \mathrm{S}$ and longitudes $22^{\circ} 45^{\prime}-$ $30^{\circ} 15^{\prime} \mathrm{E}$. It is bounded by the sea in the east and the drier Karoo (semi-desert vegetation) in the west [25]. These areas consist of villages which are generally classified as rural and poor. Prof. DS. Grierson of the Department of Botany, University of Fort Hare, authenticated the species. A voucher specimen was prepared and deposited in the herbarium of the Department of Botany (Jimoh Med. 2006/7). The plant material was allowed to air-dry at ambient temperature $\left( \pm 24{ }^{\circ} \mathrm{C}\right)$ and then milled. Twenty grams each of the sample were extracted with $200 \mathrm{~mL}$ each of acetone, methanol, and water, respectively, at ambient temperature, with agitation for 18-24 h. Each extract was filtered using Whatman no. 1 filter paper and concentrated under reduced pressure to dryness below $40^{\circ} \mathrm{C}$. The water extract was freeze-dried. The extract yields (w/w) were acetone (1.80\%), methanol $(5.6 \%)$, and water $(8.5 \%)$, respectively. The dried extracts thus obtained were used directly for the determination of the antioxidant and antibacterial activities [26]. Determinations of chemical and nutritive values of this plant were carried out using the dried sample that was ground into powder from.

\section{Chemicals}

1,1-Diphenyl-2-picrylhydrazyl (DPPH), 2,2'-azinobis-3ethylbenzothiazoline-6-sulfonic acid (ABTS), 3-(2-pyridyl)5,6-diphenyl-1,2,4-triazine-4',4"-disulfonic acid, potassium ferricyanide; catechin, butylated hydroxytoluene (BHT), ascorbic acid, catechin, tannic acid, quercetin and $\mathrm{FeCl}_{3}$ were purchased from Sigma Chemical Co. (St. Louis, MO, USA)., vanillin from BDH; Folin-Ciocalteus's phenol reagent and sodium carbonate were from Merck Chemical Supplies (Damstadt, Germany). All the other chemicals used including the solvents, were of analytical grade.

\section{Determination of Total Phenolics}

Total phenol contents in the extracts were determined by the modified Folin-Ciocalteu method [27]. An aliquot of the extract was mixed with $5 \mathrm{ml}$ Folin-Ciocalteu reagent (previously diluted with water 1:10 v/v) and $4 \mathrm{ml}(75 \mathrm{~g} / \mathrm{l})$ of sodium carbonate. The tubes were vortexed for $15 \mathrm{sec}$ and allowed to stand for $30 \mathrm{~min}$ at $40^{\circ} \mathrm{C}$ for color development. Absorbance was then measured at $765 \mathrm{~nm}$ using the Hewlett Packard UV-VS spectrophotometer. Samples of extract were evaluated at a final concentration of $0.1 \mathrm{mg} / \mathrm{ml}$. Total phenolic content were expressed as $\mathrm{mg} / \mathrm{g}$ tannic acid equivalent using the following equation based on the calibration curve: $\mathrm{y}=0.1216 \mathrm{x}, \mathrm{R}^{2}=0.9365$, where $\mathrm{x}$ was the absorbance and $\mathrm{y}$ was the tannic acid equivalent $(\mathrm{mg} / \mathrm{g})$.

\section{Determination of Total Flavonoids}

Total flavonoids were estimated using the method of Ordon ez et al. [28]. To $0.5 \mathrm{ml}$ of sample, $0.5 \mathrm{ml}$ of $2 \%$ $\mathrm{AlCl}_{3}$ ethanol solution was added. After one hour at room temperature, the absorbance was measured at $420 \mathrm{~nm}$. A yellow color indicated the presence of flavonoids. Extract samples were evaluated at a final concentration of 0.1 $\mathrm{mg} / \mathrm{ml}$. Total flavonoid content were calculated as quercetin $(\mathrm{mg} / \mathrm{g})$ using the following equation based on the calibration curve: $y=0.0255 x, R^{2}=0.9812$, where $x$ was the absorbance and was the quercetin equivalent $(\mathrm{mg} / \mathrm{g})$.

\section{Determination of Total Flavonols}

Total flavonols in the plant extracts were estimated using the method of Kumaran and Karunakaran [20]. To $2.0 \mathrm{~mL}$ of sample (standard), $2.0 \mathrm{~mL}$ of $2 \% \mathrm{AlCl}_{3}$ ethanol and $3.0 \mathrm{~mL}$ $(50 \mathrm{~g} / \mathrm{L})$ sodium acetate solutions were added. The absorption at $440 \mathrm{~nm}$ was read after $2.5 \mathrm{~h}$ at $20^{\circ} \mathrm{C}$. Extract samples were evaluated at a final concentration of 0.1 $\mathrm{mg} / \mathrm{ml}$. Total flavonoid content was calculated as quercetin $(\mathrm{mg} / \mathrm{g})$ using the following equation based on the calibration curve: $y=0.0255 x, R^{2}=0.9812$, where $x$ was the absorbance and was the quercetin equivalent $(\mathrm{mg} / \mathrm{g})$.

\section{Determination of Total Proanthocyanidins}

Determination of proanthocyanidin was based on the procedure reported by Sun et al. [29]. A volume of $0.5 \mathrm{ml}$ of $0.1 \mathrm{mg} / \mathrm{ml}$ of extract solution was mixed with $3 \mathrm{ml}$ of $4 \%$ vanillin-methanol solution and $1.5 \mathrm{ml}$ hydrochloric acid; the mixture was allowed to stand for $15 \mathrm{~min}$. The absorbance was measured at $500 \mathrm{~nm}$. Extract samples were evaluated at a final concentration of $0.1 \mathrm{mg} / \mathrm{ml}$. Total proanthocyanidin content were expressed as catechin equivalents $(\mathrm{mg} / \mathrm{g})$ using the following equation based on the calibration curve: $\mathrm{y}=$ $0.5825 \mathrm{x}, \mathrm{R}^{2}=0.9277$, where $\mathrm{x}$ was the absorbance and $\mathrm{y}$ is the catechin equivalent $(\mathrm{mg} / \mathrm{g})$. 


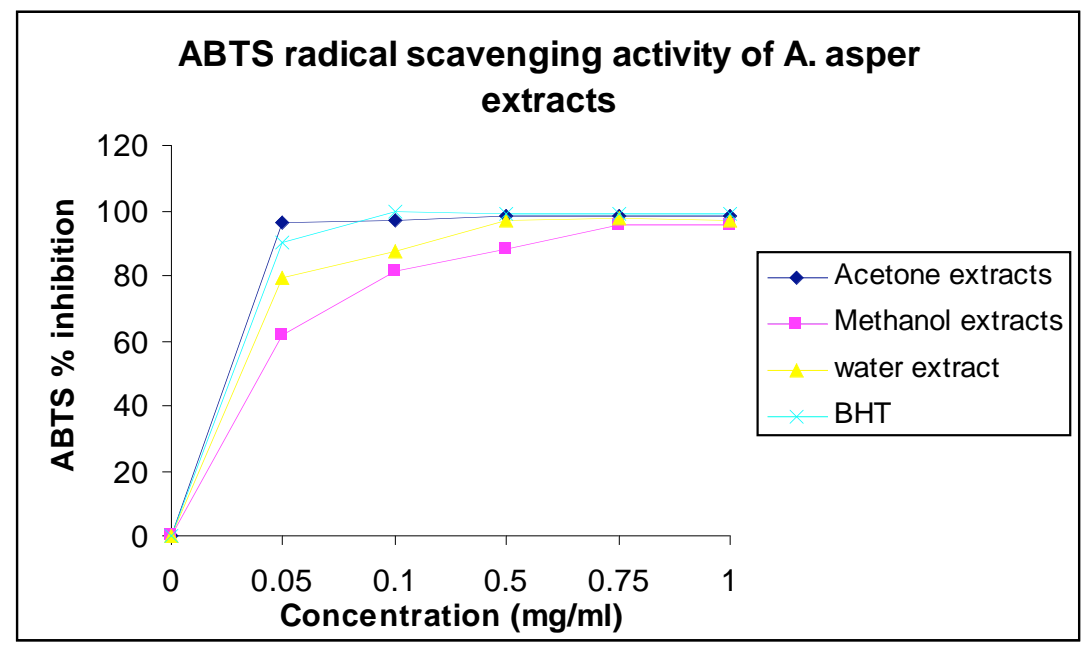

Fig. (1). ABTS radical scavenging activity of the acetone, methanol and water extracts of Amaranthus asper.

\section{Determination of Antioxidant Activity}

\section{ABTS Radical Scavenging Assay}

For ABTS assay, the method of Re et al. [30] was adopted. The stock solutions included $7 \mathrm{mM}$ ABTS ${ }^{+}$ solution and $2.4 \mathrm{mM}$ potassium persulfate solution. The working solution was then prepared by mixing the two stock solutions in equal quantities and allowing them to react for $12 \mathrm{~h}$ at room temperature in the dark. The solution was then diluted by mixing $1 \mathrm{ml} \mathrm{ABTS}{ }^{+}$solution with $60 \mathrm{ml}$ methanol to obtain an absorbance of $0.706 \pm 0.001$ units at $734 \mathrm{~nm}$ using the spectrophotometer. Fresh $\mathrm{ABTS}^{+}$solution was prepared for each assay. Plant extracts $(1 \mathrm{ml})$ were allowed to react with $1 \mathrm{ml}$ of the $\mathrm{ABTS}^{+}$solution and the absorbance was taken at $734 \mathrm{~nm}$ after $7 \mathrm{~min}$ using the spectrophoto- meter. The ABTS ${ }^{+}$scavenging capacity of the extract was compared with that of BHT and percentage inhibition calculated as ABTS radical scavenging activity $(\%)=$ $\left[\left(\mathrm{Abs}_{\text {control }}-\mathrm{Abs}_{\mathrm{sample}}\right)\right] /\left(\mathrm{Abs}_{\text {control }}\right) \mathrm{x} 100$ where $\mathrm{Abs}_{\text {control }}$ is the absorbance of ABTS radical + methanol; $\mathrm{Abs}_{\text {sample }}$ is the absorbance of ABTS radical + sample extract /standard (Fig. 1).

\section{DPPH Radical Scavenging Assay}

The effect of extracts on DPPH radical was estimated using the method of Liyana-Pathirana and Shahidi [31]. A solution of $0.135 \mathrm{mM}$ DPPH in methanol was prepared and $1.0 \mathrm{ml}$ of this solution was mixed with $1.0 \mathrm{ml}$ of extract in methanol containing $0.02-0.1 \mathrm{mg}$ of the extract. The reaction mixture was vortexed thoroughly and left in the dark at room

DPPH radical scavenging activity of $A$. asper

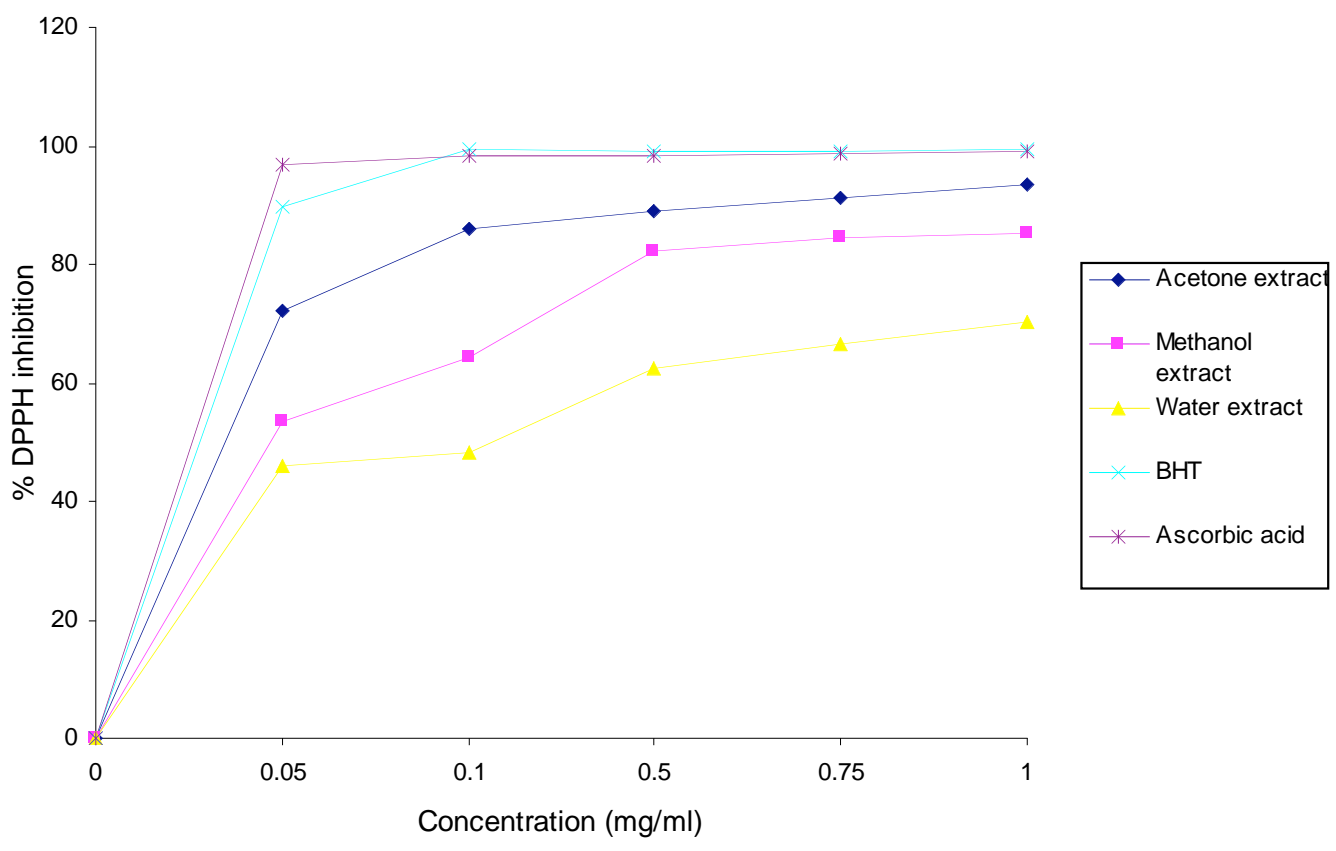

Fig. (2). DPPH radical scavenging activities of the acetone, methanol and acetone extracts of Amaranthus asper. 
temperature for $30 \mathrm{~min}$. The absorbance of the mixture was measured spectrophotometrically at $517 \mathrm{~nm}$. Ascorbic acid and BHT were used as references. The ability to scavenge DPPH radical was calculated by the following equation: DPPH radical scavenging activity $(\%)=\left[\left(\mathrm{Abs}_{\text {control }}\right.\right.$ $\left.\left.\mathrm{Abs}_{\text {sample }}\right)\right] /\left(\mathrm{Abs}_{\text {control }}\right] \quad \mathrm{x} 100$ where $\mathrm{Abs}_{\text {control }}$ is the absorbance of DPPH radical + methanol; $\mathrm{Abs}_{\text {sample }}$ is the absorbance of DPPH radical + sample extract /standard.

\section{Total Antioxidant Activity (FRAP Assay)}

A modified method of Benzie and Strain [32] was adopted for the FRAP assay. The stock solutions included $300 \mathrm{mM}$ acetate buffer $\left(3.1 \mathrm{~g} \mathrm{C}_{2} \mathrm{H}_{3} \mathrm{NaO}_{2} \cdot 3 \mathrm{H}_{2} \mathrm{O}\right.$ and $16 \mathrm{ml}$ $\left.\mathrm{C}_{2} \mathrm{H}_{4} \mathrm{O}_{2}\right), \mathrm{pH}$ 3.6, $10 \mathrm{mM}$ TPTZ (2, 4, 6-tripyridyl-s-triazine) solution in $40 \mathrm{mM} \mathrm{HCl}$, and $20 \mathrm{mM} \mathrm{FeCl} \cdot 6 \mathrm{H}_{2} \mathrm{O}$ solution. The fresh working solution was prepared by mixing $25 \mathrm{ml}$ acetate buffer, $2.5 \mathrm{ml} \mathrm{TPTZ}$, and $2.5 \mathrm{ml} \mathrm{FeCl} \cdot 6 \mathrm{H}_{2} \mathrm{O}$. The temperature of the solution was raised to $37^{\circ} \mathrm{C}$ before using. Plant extracts $(150 \mu \mathrm{L})$ were allowed to react with $2850 \mu \mathrm{L}$ of the FRAP solution for $30 \mathrm{~min}$ in the dark condition. Readings of the colored product (ferrous tripyridyltriazine complex) were taken at $593 \mathrm{~nm}$. The standard curve was linear between 200 and $1000 \mu \mathrm{M} \mathrm{FeSO}$. Results are expressed in $\mu \mathrm{M} \mathrm{Fe}$ (II)/g dry mass and compared with that of BHT, ascorbic acid and catechin.

\section{Proximate Analysis}

The recommended methods of the Association of Official Analytical chemists (AOAC, 1999) were used for the determination of moisture, ash, crude lipid, crude fibre and nitrogen content.

\section{Mineral Analysis}

The automated procedure for determining cations in the plant material utilizes the reaction between a particular cation and molybdovanate to form a complex. The complex is then measured colorimetrically at $420 \mathrm{~nm}$. The elements comprising sodium, calcium, potassium, magnesium, iron, zinc, copper, manganese, potassium, nitrogen and phosphorus were determined in this way.

\section{Anti-nutrient Analysis}

Determination of alkaloid and saponins were as described by Obadoni and Ochuko [33]. Phytate was estimated by the method of Wheeler and Ferrel [34].

\section{Bioassay}

The bacterial cultures used in this study were obtained from the Department of Biochemistry and Microbiology, Rhodes University, South Africa. They consisted of five Gram-positive and five Gram- negative strains (Table VI). Each organism was maintained on nutrient agar plates and was recovered for testing by growth in nutrient broth for 24 hrs. Before use, each bacterial culture was diluted 1:100 with fresh sterile nutrient broth [35].

Test organisms were streaked in a radial pattern on sterile nutrient agar plates containing filtered extracts at final concentrations of $0.1,0.5,1.0,2.5$ and $5.0 \mathrm{mg} / \mathrm{ml}[23,36]$. Plates containing only nutrient agar and another set containing nutrient agar and the respective solvents served as controls. After inoculation, the plates were incubated at $37^{\circ} \mathrm{C}$ for 24 to 48 hours. Each treatment was performed in triplicate and complete inhibition of bacterial growth was required for an extract to be declared bioactive. The antibacterial activities of the extracts were compared to those of streptomycin and chloramphenicol.

\section{Statistical Analysis}

The experimental results were expressed as mean \pm standard deviation (SD) of three replicates. Where applicable, the data were subjected to one way analysis of variance (ANOVA) and differences between samples were determined by Duncan's Multiple Range test using the Statistical Analysis System (SAS, 1999) program. $P$ Values $<0.05$ were regarded as significant and $P$ values $<0.01$ as very significant.

\section{RESULTS}

\section{ABTS}

At $0.05 \mathrm{mg} / \mathrm{ml}$, the acetone extract caused $96.5 \%$ ABTS radical scavenging inhibition while the methanol, water, and BHT caused inhibition at $61.8,79.1$ and $89.8 \%$ respectively. At $1 \mathrm{mg} / \mathrm{ml}$, the results were $98.2,95.4,97.1$ and $99.3 \%$ for acetone, methanol, water and BHT respectively.

\section{DPPH}

At $0.05 \mathrm{mg} / \mathrm{ml}$, the acetone, methanol, water, BHT and ascorbic acid caused DPPH radical scavenging activity at $72.5,53.5,46.0,93.1$ and $99.8 \%$ respectively while at $1 \mathrm{mg} / \mathrm{ml}$, the results were $93.5,85.4,70.5,100$ and $100 \%$ for acetone, methanol, water, BHT and ascorbic acid respectively.

\section{Polyphenolic Contents}

With respect to the total polyphenol, the acetone extract has higher content of this constituent than that of methanol and acetone. The flavonoid contents of the water extract is higher than those of acetone and methanol at 1.15, 0.80 and 0.96 respectively. The methanol extract had higher content of proanthocyanidins relative to acetone and water extracts at $2.42,1.9$ and 0.73 respectively. In the case of total flavonol, methanol extract also have higher contents than acetone and water extracts i.e. 0.96, 0.43 and 0.43 , respectively (Table 1).

Table 1. Polyphenol Contents of the Acetone, Methanol and Water Extracts of the Leaves of Amaranthus asper $(n=3, X \pm$ SEM $)$

\begin{tabular}{|c|c|c|c|}
\hline Phenolics & Acetone & Methanol & Water \\
\hline \hline Total polyphenol $^{\mathrm{a}}$ & $22.77 \pm 0.95^{*}$ & $13.89 \pm 1.62^{*}$ & $7.25 \pm 1.43$ \\
Flavonoids $^{\mathrm{b}}$ & $0.80 \pm 0.04$ & $0.96 \pm 0.11$ & $1.15 \pm 0.03^{*}$ \\
Proanthocyanidins $^{\mathrm{d}}$ & $1.90 \pm 0.43^{*}$ & $2.42 \pm 0.37^{*}$ & $0.73 \pm 0.31$ \\
Total Flavonol $^{\mathrm{c}}$ & $0.43 \pm 0.03$ & $0.96 \pm 0.25^{*}$ & $0.43 \pm 0.14$ \\
\hline
\end{tabular}

${ }^{\mathrm{a}}$ Expressed as mg tannic acid/g of dry plant material.

${ }^{b}$ Expressed as mg quercetin/g of dry plant material.

${ }^{c}$ Expressed as mg quercetin/g of dry plant material.

${ }^{\mathrm{d}}$ Expressed as mg quercetin/g of dry plant material

* indicates that this value is significantly different from the other at $\mathrm{P}<0.05$ 


\section{Total Antioxidant Power (FRAP)}

The ferrous reducing antioxidant power (FRAP) values for acetone extract (10.84.9) is much higher than that of methanol (143.5), water (42.4), BHT (63.5), and catechin (972.02) but lower than those of ascorbic acid (1632.1) and quercetin (3107.3) (Table 2).

Table 2. FRAP Activity of the Acetone, Methanol and Water Extracts of Amaranthus asper

\begin{tabular}{|c|c|}
\hline Extracts & FRAP $^{\mathbf{e}}$ \\
\hline \hline Acetone & $1084.91 \pm 122.7$ \\
Methanol & $143.48 \pm 11.59$ \\
Water & $42.39 \pm 14.53$ \\
Ascorbic acid & $1632.1 \pm 16.95$ \\
BHT & $63.46 \pm 2.49$ \\
Catechin & $972.02 \pm 0.61$ \\
Quercetin & $3107.29 \pm 31.28$ \\
\hline
\end{tabular}

${ }^{e}$ Expressed in units of $\mu \mathrm{mol} \mathrm{Fe}$ (II)/g.

\section{Proximate analysis}

The proximate analysis showed the percentage moisture content, ash content, crude protein, crude lipid, crude fibre and carbohydrate of the leaves as $70.5,18.5,11.13,4.0,17.5$ and $48.8 \%$, respectively while its calorific value is 275.9 $\mathrm{Kcal} / 100 \mathrm{~g}$ (Table 3). Elemental analysis in mg/100 g (DW) indicated that the leaves contained sodium (0.0373), potassium (2.872), calcium (2.504), Magnesium (0.569), Iron (419), Zinc (26), phosphorus (0.177), Copper (18), Manganese (91), and Nitrogen (1.78) (Table 4).

Table 3. Proximate Analysis of the Leaves of Amaranthus asper

\begin{tabular}{|c|c|}
\hline Constituents & Value \\
\hline \hline Moisture & $70.48 \pm 5.48$ \\
Ash & $18.5 \pm 0.4$ \\
Protein & $11.13 \pm 0.11$ \\
Fat & $4.0 \pm 0.2$ \\
Carbohydrate & $48.84 \pm 2.1$ \\
Crude fibre & $17.53 \pm 1.87$ \\
Energy (kcal) & $275.88 \pm 3.2$ \\
\hline
\end{tabular}

Table 4. Macro and Micro Elements Constituents of the Leaves of Amaranthus asper

\begin{tabular}{|c|c|}
\hline Macro and Micro elements & Value (mg/100g dwb) \\
\hline \hline Magnésium & 0.569 \\
Calcium & 2.504 \\
Potassium & 2.872 \\
Phosphorus & 0.177 \\
Sodium & 0.0373 \\
Iron (ppm) & 419 \\
Zinc & 26 \\
Copper & 18 \\
Manganese & 91 \\
Total Khedjal nitrogen & 1.78 \\
\hline
\end{tabular}

\section{Anti-Nutrient Contents}

The chemical composition in $\mathrm{mg} / 100 \mathrm{~g}$ (DW) for alkaloid, saponins, and phytate were $0.3,7.0$ and 9.25, respectively (Table $\mathbf{5}$ ).

Table 5. Analysis of Anti-Nutrients Contents of A. asper

\begin{tabular}{|c|c|}
\hline Anti-nutrients & Value (mg/100g dwb) \\
\hline \hline Alkaloids & $0.30 \pm 0.05$ \\
Saponins & $7.0 \pm 0$ \\
Phytate & $9.25 \pm 0.3$ \\
\hline
\end{tabular}

\section{Antibacterial Assay}

The methanol extract of this plant has activity against all the Gram positive organisms used in this study at $5 \mathrm{mg} / \mathrm{ml}$ concentration. The acetone extract on the other hand has activity against Bacillus cereus $(1 \mathrm{mg} / \mathrm{ml})$, Micrococcus kristinae $(1 \mathrm{mg} / \mathrm{ml})$, Staphylococcus aureus $(5 \mathrm{mg} / \mathrm{ml})$ and Streptococcus pyrogens $(2 \mathrm{mg} / \mathrm{ml})$. The water extract only has activity against Micrococcus kristinae $(1 \mathrm{mg} / \mathrm{ml})$ and Escherichia coli $(2 \mathrm{mg} / \mathrm{ml})$ (Table 6).

\section{DISCUSSION}

Polyphenols are the major plant compounds with antioxidant activity. This activity is believed to be mainly due to their redox properties [37], which play an important role in adsorbing and neutralizing free radicals, quenching singlet and triplet oxygen, or decomposing peroxides. The results strongly suggest that phenolics are important components of these plants, and some of their pharmacological effects could be attributed to the presence of these valuable constituents.

The antioxidant potentials of the extracts of the leaves of this plant were estimated from their ability to reduce TPRZFe (III) complex to TPTZ-Fe (II). According to recent reports, a highly positive relationship between total phenols and antioxidant activity appears to be the trend in many plant species [27].

Proton radical scavenging is an important attribute of antioxidants. ABTS, a protonated radical, has characteristic absorbance maxima at $734 \mathrm{~nm}$ which decreases with the scavenging of the proton radicals [38]. Higher concentrations of the extracts were more effective in quenching free radicals in the system.

The effect of antioxidants on DPPH is thought to be due to their hydrogen donating ability [39]. The DPPH radical scavenging abilities of the acetone extract at $1 \mathrm{mg} / \mathrm{ml}$ was significantly comparable to those of ascorbic acid (100\%) and BHT (100), showing that the extract has the protondonating ability and could serve as free radical inhibitors or scavengers, acting possibly as primary antioxidants. The results for methanol (85.4) and water (70.5) are not as high. The scavenging of the ABTS radical by the extracts at $1 \mathrm{mg} / \mathrm{ml}$ was found to be slightly higher than that of DPPH ${ }^{*}$ radical. Factors like stereoselectivity of the radicals or the solubility of the extract in different testing systems have been reported to affect the capacity of extracts to react and 
Table 6. Antibacterial Activity of the Leaves Extracts of Amaranthus asper

\begin{tabular}{|c|c|c|c|c|c|c|}
\hline \multirow{2}{*}{ Bacterial species } & \multirow{2}{*}{ Gram +/- } & \multicolumn{4}{|c|}{ Minimum inhibitory concentration (mg/ml) } \\
\cline { 3 - 7 } & & Acetone & Methanol & Water & Chloramphenicol & Streptomycin \\
\hline \hline Bacillus cereus & + & 1.0 & 5.0 & na & $<2$ & $<2$ \\
Staphylococcus epidermidis & + & na & 5.0 & na & $<2$ & $<2$ \\
Staphylococcus aureus & + & 5.0 & 5.0 & na & 2.0 & $<2$ \\
Micrococcus kristinae & + & 1.0 & 5.0 & na & $<2$ & $<2$ \\
Streptococcus pyrogens & + & 2.0 & na & na & 2.0 & $<2$ \\
Escherischia coli & - & na & na & na & $<2$ & $<2$ \\
Salmonella pooni & - & na & na & na & $<2$ & $<2$ \\
Serratia marcescens & - & na & na & na & $<2$ & $<2$ \\
Pseudomonas aeruginosa & - & na & na & na & $<2$ \\
Klebsiella pneumonae & - & & & & $<2$ \\
\hline
\end{tabular}

$\mathrm{Na}=$ not active.

quench different radicals [40]. Wang et al. [41] found that some compounds which have ABTS scavenging activity did not show DPPH scavenging activity.

The antibacterial activity of the extracts of the leaves of the plant is presented in Table 6. It has just been shown that the plant extracts were active against the Gram-positive and one Gram-negative strain $(E$. coli). This observation therefore supports the fact that, in general, the Gramnegative bacteria are more resistant than the Gram positive ones [42, 43]. Since these extracts show some activity against some of the organisms used in this study; the use of this plant for medicinal purpose may be justified.

The results of proximate composition of A. asper leaves (Table 3) show high moisture content ( $70.5 \%$ wet weight). This is however below reported range (81.4-90.3\%) in some Nigerian green leafy vegetables [2]. Ash content, which is an index of mineral contents in biota, is $18.5 \% \mathrm{DW}$ in $A$. asper and this compare favourably with the values reported for Ipomea batatas (11.10\%), Vernonia colorate (15.86\%) and Moringa oleifera (15.09\% DW) [3, 44]. It is also, higher than that of some Nigerian leafy vegetable such as Ocimum gratissium (18.00\% DW) and Hibiscus esculentus $(8.00 \%$ DW) [4]. The crude protein content of A. asper L $(11.13 \%$ DW) is higher than protein content of Momor-dica foecide $(4.6 \%)$ leaves consumed in Nigeria and Swaziland [6, 45, 46], but lower than those of I. batatas (24.85\% DW), Amaranthus candatus (20.5\% DW), Piper guineeses (29.78\% DW) and T. triangulare (31.00\% DW) [4, 44, 47]. According to Pearson [48], plant food that provides more than $12 \%$ of its calorific value from protein is considered good source of protein. Though, the protein content of $A$. asper leaves is 11.13 and is slightly lower than this requirement may nonetheless go a long way in meeting the protein requirement of the local people.

A. asper leaf is a poor source of lipid because the crude lipid content $(4.0 \% \mathrm{DW})$ is low compared to reported values $(8.3-27.0 \% \mathrm{DW})$ in some vegetables consumed in West Africa $[49,50]$. However, it compares favorably with $4.20 \%$ reported for Calchorus africanum leaves and 1.85-8.71\% DW in some edible green leafy vegetables of Southern India and Nigeria [51, 52]. The carbohydrate content of the plant $(48.8 \%$ DW) is higher than 20, 23.7 and $39.05 \%$ reported for Senna obtusfolia, Amaranthus incurvatus, M. balsamina leaves, respectively $[6,53]$. This is however; lower than reported values for Corchorus tridens $(75.0 \% \mathrm{DW})$ and sweet potatoes leaves $(82.8 \%)$ [54]. The recommended dietary allowance (RDA) values for children, adults, pregnant and lactating mothers are $130 \mathrm{~g}, 130,175$ and 210 g, respectively [2]. It implies that $40,40,30$ and $25 \%$ of their respective daily requirement can be met when $100 \mathrm{~g}$ dried leaves are consumed.

The crude fibre content $(17.5 \% \mathrm{DW})$ is high when compared to Ipomea batatas $(7.20 \%), T$. triangulare $(6.20 \%)$ P. guineeses (6.40\%), Corchorus olitorius (7.0\%) Vernonia amagydalina $(6.5 \%)$ [4, 44]. Adequate intake of dietary fibre can lower the serum cholesterol level, risk of coronary heart disease, hypertension, constipation, diabetes, colon and breast cancer $[12,55]$. The RDA of fibre for children, adults, pregnant and lactating mothers are $19-25,21-38,28$ and 29 $\mathrm{g}$, respectively. The estimated calorific value $(275.9 \mathrm{kcal} / 100$ g DW) in A. asper leaves compare favourably to $248.8-$ $307.1 \mathrm{Kcal} / 100 \mathrm{~g}$ DW reported in some Nigerian vegetables [2, 44, 56]. Asibey-Berko and Tayie [54] also reported comparable energy content in some Ghanaian green leafy vegetables. Thus, the calorific value agreement with general observation that vegetables have low energy values [57].

The mineral composition of A. asper is as shown in Table 4. The $\mathrm{Na} / \mathrm{K}$ ratio in the body is of great concern for prevention of high blood pressure. $\mathrm{Na} / \mathrm{K}$ ratio less than one is recommended [58]. Hence, consumption of $A$. asper would probably reduce high blood pressure diseases because its $\mathrm{Na} / \mathrm{K}$ is less than one. Iron content of the leaves (419 $\mathrm{mg} / 100 \mathrm{~g}$ ) is very high when compare with the value reported in I batatas (16.00 $\mathrm{mg} / 100 \mathrm{~g})$ [44]. Iron is an essential trace element for haemoglobin formation, normal functioning of the central nervous system and in the oxidation of carbohydrates, protein and fats [2, 59]. The Zinc content $(26 \mathrm{mg} / 100 \mathrm{~g})$ compares favourably to most values reported for green leafy vegetables in literatures [6, 60]. Zinc is involved in normal function of immune system.

Analysis of the antinutrient contents of the plant showed that alkaloid $(0.3 \mathrm{mg} / 100 \mathrm{~g})$ saponins $(7.0 \mathrm{mg} / 100 \mathrm{~g})$ and phytate $(9.3 \mathrm{mg} / 100 \mathrm{~g})$ were present. The alkaloid content $(0.3 \mathrm{mg} / 100 \mathrm{~g})$ is lower than the values reported for the leafy vegetables Aspilia Africanaa, Bryophyllum pinnatum), Cleome rutidosperma and Emilia coccinea consumed in 
Nigeria $[2,61,62]$. The saponin content $(7.0 \mathrm{mg} / 100 \mathrm{~g})$ is much less than the value reported for some medicinal plants used in Nigeria. Though the phytate $(9.3 \mathrm{mg} / 100 \mathrm{~g})$ is higher than the value reported for I. batatas and G. africana leaves $[44,49]$ is still within the tolerable limits and can easily be detoxified by soaking, boiling or frying [2, 63-65].

The results of this study showed that the leaves of $A$. asper contain appreciable amount of proteins, fat, fibre, carbohydrate and calorific value, mineral elements, polyphenols, and generally low level of toxicants. Its antioxidant and antibacterial activities further lend credence to the biological value of this plant. Thus, it can therefore be concluded that $A$. asper leaves can contribute significantly to the nutrient requirements of man and should be used as a form of nutrients to supplement other major sources. Its medicinal value is also of great interest.

\section{ACKNOWLEDGEMENT}

The authors are grateful to the National Research Foundation (NRF) of South Africa for funding this research.

\section{REFERENCES}

[1] Ladeji O, Okoye ZS, Ojobe T. Chemical evaluation of the nutritive value of leaf of fluted pumpkin (Telferia occidentalis). Food Chem 1995; 53: 353-5.

[2] Akubugwo IE, Obasi NA, Chinyere GC, Ugbogu AE, 8Nutritional and chemical value of Amaranthus hybridus L. leaves from Nigeria Afr J Biotechnol 2007; 6 (24): 2833-9.

[3] Lockeett CT, Calvert CC, Grivetti LE. Energy and micronutrient Composition of dietary and Medicinal wild plants Consumed during drought: Study of Rural Fulani, Northeastern Nigeria. Int J Food Sci Nutr 2000; 51: 195-208.

[4] Akindahunsi AA, Salawu SO. Photochemical screening and nutrient-anti-nutrient composition of selected tropical green vegetables. Afr J Biotechnol 2005; 4: 497-501.

[5] Edeoga HO, Omosun G, Uche LC. Chemical composition of Hyptis sauveolens and Ocimum gratissium hybrids from Nigeria. Afr $\mathrm{J}$ Biotechnol 2006; 5(10): 892-5.

[6] Hassan LG, Umar KJ. Nutritional value of Balsam Apple (Momordica balsamina L.) leaves. Pak J Nutr 2006; 5(6): 522-9.

[7] Ekop AS, Eddy NO. Comparative Studies of the level of toxicants in the seed of Indian Almond (Terminalia catappa) and African walnut (Coula edulis). Chem Class J 2005; 2: 74-6.

[8] Mepha HD, Eboh L, Banigbo DEB. Effects of processing treatments on the Nutritive Composition and consumer acceptance of some Nigerian edible leafy vegetables. Afr J Food Agric Nutr Dev 2007; 7(1): 1-18.

[9] Dhellot JR, Matouba E, Maloumbi MG, et al. Extraction, chemical composition and nutritional characterization of vegetable oils: Case of Amaranthus hybridus (Var 1 and 2) of Congo Brazzaville. Afr J Biotechnol 2006; 5(11): 1095-101.

[10] Oliveria JS, DeCarvalho MF. Nutritional Value of some edible leaves in Mozambique. Econ Bot 1975; 29: 255-9.

[11] Martin FW, Telek L. Vegetables for the hot humid. Part 6: Amaranth and Celosia. U.S. Dept of Agric., New Orleans, LA, 1979; pp. 156-63.

[12] Rao CV, Newmark HL, Chemo-preventive effect of Squalene on colon cancer. Carcinogenesis 1998; 19: 287-90.

[13] Smith TJ. Squalene: potential chemo preventive agent. Expert Opin Invest Drugs 2000; 9: 1841-8.

[14] He HP, Corke H. Oil and squalene in Amaranthus Grain and leaf. J Agric food Chem 2003; 51(27): 7913-20.

[15] Gerber M, Boutron-Ruault MC, Hercberg S, Riboli E, Scalbert A, Siess MH. Food and cancer: state of the art about the protective effect of fruits and vegetables. Bull Cancer 2002; 89: 293-312.

[16] Kris-Etherton PM, Hecker KD, Bonanome A, Coval SM, Binkosi $\mathrm{AE}$, Hilpert KF. Bioactive compounds in foods: their role in the prevention of cardiovascular disease and cancer. Am J Med 2002; 113: 71S-88S.

[17] Serafini M, Bellocco R, Wolk A, Ekstrom AM. Total antioxidant potential of fruit and vegetables and risk of gastric cancer. Gastroenterology 2002; 123: 985-91.

[18] Di Matteo V, Esposito E. Biochemical and therapeutic effects of antioxidants in the treatment of Alzheimer's disease, Parkinson's disease, and amyotrophic lateral sclerosis. Curr Drug Target CNS Neurol Disord 2003; 2: 95-107.

[19] Ame SN, Shigrenaga MK, Hagen TM. Oxidants, antioxidants and degenerative diseases of ageing. Proc Natl Acad Sci USA 1993; 90 : 7915-22.

[20] Kumaran A, Karunakaran RJ. Antioxidant and free radical scavenging activity of an aqueous extract of Coleus aromaticus. Food Chem 2006; 97: 109-14.

[21] Meurer-Grimes B, Mcbeth DL, Hallihan B, Delph S. Antimicrobial activity in medicinal plants of the Scrophulariaceae and Acanthaceae. Pharm Biol 1996; 34: 243- 8.

[22] Rabe T, Van Staden J, Antibacterial activity of South African plants used for medicinal purposes. J Ethnopharmacol 1997; 56: 81-7.

[23] Koduru S, Grierson DS, Afolayan AJ. Antimicrobial activity of Solanum aculeastrum. Pharm Biol 44 (4): 283-6.

[24] Mathekaga ADM, Meyer JJM. Antibacterial activity of South African Helichrysum species. S Afr J Bot 1998; 64: 293-5.

[25] Masika PJ, Afolayan AJ. An ethnobotanical study of plants used for the treatment of livestock diseases in the Eastern Cape Province, South Africa. Pharm Biol 2003; 41: 16-21.

[26] Taylor RSL, Edel F, Manandhar NP, Towers GHN. Antimicrobial activity of southern Nepalese medicinal plants. J Ethnopharmacol 1996; 45: 67-70.

[27] Wolfe K, Wu X, Liu RH, Antioxidant activity of apple peels. J Agric Food Chem 2003; 51: 609-14.

[28] Ordoñez AAL, Gomez JG, Vattuone MA, Isla MI Antioxidant activities of Sechium edule (Jacq.) Swart extracts. Food Chem 2006; 97: 452-8.

[29] Sun JS, Tsuang YW, Chen IJ, Huang WC, Hang YS, Lu FJ. An ultra-weak chemiluminescence study on oxidative stress in rabbits following acute thermal injury. Burns 1998; 24: 225-31.

[30] Re R, Pellegrini N, Proteggente A, Pannala A, Yang M, Rice-Evans C. Antioxidant activity applying an improved ABTS radical cation decolorization assay. Free Radic Biol Med 1999; 26: 1231-7.

[31] Liyana-Pathiranan CM, Shahidi F. Antioxidant activity of commercial soft and hard wheat (Triticum aestivum $L$ ) as affected by gastric pH conditions. J Agric Food Chem 2005; 53: 2433-40.

[32] Benzie IFF, Strain JJ. The ferric reducing ability of plasma (FRAP) as a measure of "antioxidant power": the FRAP assay. Anal Biochem 1996; 239: 70-6.

[33] Obadoni BO, Ochuko PO. Phytochemical studies and comparative efficacy of the Crude extracts of some homeostatic plants in Edo and Delta States of Nigeria. Global J Pure Appl Sci 2001; 8: 203-8.

[34] Wheeler VE, Ferrel FE, A method of phytic acid determination in wheat fraction. Cereal Chem 1971; 48: 312-6.

[35] Afolayan AJ, Meyer JJM, The antimicrobial activity of 3, 5, 7trihydroxyflavone isolated from the shoot of Helichrysum aureonitens. J Ethnopharmacol 1997; 57: 177-81.

[36] Meyer JJM, Afolayan AJ. Antibacterial activity of Helichrysum aureonitens (Asteraceae). J Ethnopharmacol 1995; 47: 109-11.

[37] Wichi HP, Enhanced tum from the perspective effect on forestomach and oesophageal squamous epithelium. Food Chem Toxicol 1988; 26: 717-23.

[38] Yoshida H, Takagi S, Antioxidative effects of sesamol and tocopherols at various concentrations in oils during microwave heating. J Sci Food Agric 1999; 79: 220-6.

[39] Yu L, Haley S, Perret J, Harris M, Wilson J, Qian M. Free radical scavenging properties of wheat extracts. J Agric Food Chem 2002; 50: $1619-24$.

[40] Zheng W, Wang YS, Antioxidant activity and phenolic compounds in selected herbs. J Agric Food Chem 2001; 49: 5165-70.

[41] Wang M, Li J, Rangarajan M, Shao Y, La Voie EJ, Huang T, Ho C, Antioxidative phenolic compounds from Sage (Salvia officinalis). J Agric Food Chem 1998; 46: 4869-73.

[42] Grierson DS, Afolayan AJ. Antibacterial activity of some indigenous plants used for the treatment of wounds in the Eastern Cape, South Africa. J Ethnopharmacol 1999; 66: 103-6.

[43] Afolayan AJ, Extracts from the shoots of Arctotis arctotoides inhibit the growth of bacteria and fungi. Pharm Biol 2003; 41: 22-5. 
[44] Antia BS, Akpan EJ, Okon PA, Umoren IU. Nutritive and AntiNutritive Evaluation of sweet potatoes (Ipomoea batatas) leaves. Pak J Nutr 2006; 5(2): 166-8.

[45] Ogle BM, Grivetti LE. Legacy of the chameleon: Edible wild plants in the Kingdom of Swaziland, Southern Africa. A cultural, ecological nutritional study. Part IV: Nutritional analysis and conclusion. Ecol Food Nutr 1985; 17: 41-64.

[46] Isong EU, Idiong UI. Comparative studies on the nutritional and toxic composition of three varieties of Leianthera africana. Plants Food Hum Nutr 1997; 51: 79-84.

[47] Etuk EU, Bassey MN, Umoh UO, Inyang EG. Comparative nutritional studies on three local varieties of Heinsia crinita. Plant Varieties Seeds 1998; 11: 151-8.

[48] Pearson D. Chemical analysis of foods. $7^{\text {th }}$ ed. London, churchchill, Livingstone, 1976; pp. 218-336.

[49] Ifon ET, Bassir O. The nutritive value of some Nigerian leafy vegetables- parts 2: The distribution of proteins, Carbohydrates (including ethanol-soluble simple sugars), Crude fat, Fibre and Ash. Food Chem 1980; 5: 231-5.

[50] Sena LP, VanderJagt DJ, Rivera C, et al. Analysis of Nutritional Components of eight famine foods of the Republic of Niger. Plant Foods Hum Nutr 1998, 52: 17-30.

[51] Agbo JT, Proximate nutrient composition of sickle pod. (Cassia obtusfolia) leaves and seeds. Plants Prod Res J 2004; 8: 13-7.

[52] Gupta S, Lakshmi AJ, Majunath MN, Prakash J. Analysis of nutrient and antinutrient content of underutilized green leafy vegetables. LWT-Food Sci Technol 2005; 38: 339-45.

[53] Faruq UZ, Sani A, Hassan LG. Proximate composition of sickle pod. (Senna obtusfolia) leaves. Niger J Basic Appl Sci 2002; 11: 157-64.

[54] Asibey-Berko E, Tayie FAK. Proximate analysis of some underutilized Ghanaian vegetables. Ghana J Sci 1999; 39: 91-2.
[55] Ishida H, Suzuno H, Sugiyama N, Innami S, Todokoro T, Maekawa A. Nutritional evaluation of chemical component of leaves, stalks and stems of sweet potatoes (Ipomea batatas poir). Food Chem 2000; 68: 359-67.

[56] Isong EU, Adewusi SAR, Nkanga EU, Umoh EE, Offiong EE. Nutritional and phytogeriatological studies of three varieties of Gnetum africanum (afang). Food Chem 1999; 64: 489-93.

[57] Lintas C. Nutritional aspects of fruits and vegetable consumption. Options Mediterr 1992; 19: 79-87.

[58] Food and nutrition board, Institute of medicine. National Academy of Sciences. Dietary reference Intake for Energy, Carbohydrate, Fibre, Fat, Fatty Acids, Cholesterol, protein and Amino acid (micro-nutrients). www.nap.edu FND 2002.

[59] Adeyeye E, Otokili MKO, Proximate composition and some nutritionally valuable minerals of two varieties of Capsicum annum (Bell and cherry peppers). Discov Innov 1999; 11: 75-81.

[60] Ibrahim NDG, Abdurahhman EM, Ibrahim G. Elemental analysis of the leaves of Vernonia amygdalina and its biological evaluation in rats. Niger J Nat Prod Med 2001; 5: 13-6.

[61] Edeoga HO, Okwu DE, Mbaebie BO. Phytochemical constituents of some Nigerian Medicinal plants. Afr J Biotechnol 2005; 4(7): 685-8.

[62] Okwu DE, Josiah C. Evaluation of the chemical composition of two Nigerian Medical plants. Afr J Biotechnol 2006; 5(4): 357-61.

[63] Eka OU, Osagie AU. Nutritional quality of plant food. University of Benin, Nigeria. Post Harvest publishers 1998; pp. 38-54.

[64] Ekop AS, Eddy ND, Udofia PG, Effect of Processing on the elemental composition of beans. Proceedings of $28^{\text {th }}$ Annual Conference of Nigeria Institute of Food Science and Technology (NIFEST), Ibadan 2004; pp. 217-8.

[65] Ekop AS. Determination of chemical composition of Gnetum africana (AFANG) seeds. Pak J Nutr 2007; 6(1): 40- 3.

(C) Jimoh et al.; Licensee Bentham Open.

This is an open access article licensed under the terms of the Creative Commons Attribution Non-Commercial License (http://creativecommons.org/licenses/by$\mathrm{nc} / 3.0 /$ ), which permits unrestricted, non-commercial use, distribution and reproduction in any medium, provided the work is properly cited. 